JOIPAD : Journal of Islamic Philanthropy and Disaster

Vol. : : 1 (2), 2021, 134-151

DOI : :10.21154/joipad.v1i2.3042

p-ISSN : 2807-8071

e-ISSN : 2807-7113

The Effect Of Zakat Knowledge and Religiusity on Community Awareness to Paying Zakat for Rice Agriculture (Case Study: Lembah Village, Dolo, Madiun Indonesia)

\title{
Erfinasari $^{1}$, Asmak Ab Rahman, ${ }^{2}$ Shinta Maharani. ${ }^{3}$
}

${ }^{1,3}$ Faculty of Economics and Islamic Business, State Institute of Islamic Studies Ponorogo, maharani@iainponorogo.ac.id

${ }^{2}$ Department of Sharia and Economics, Academy of Islamic Studies, The University of Malaya Malaysia.

\section{ABSTRACT}

The population of Lembah Village, Dolopo District, Madiun Regency is 4,006 people, and 1,023 residents work as farmers, and the area of rice fields is $216 \mathrm{Ha}$. Seeing the extent of available land shows that zakat's potential in the agricultural sector, especially rice in the region, is quite significant. However, the reality in people's lives, especially in Lembah Village, has not been fully implemented to pay zakat on agriculture. It is due to the lack of public knowledge regarding zakat, especially zakat on rice farming. So far, the management of zakat in this sector has not been entirely appropriately managed. The zakat collected so far has not been submitted to an official institution established by the government. So far, zakat payments for agricultural products are only based on public awareness, and it is not uncommon for those who do not pay zakat for agricultural products. This research focuses on the following problems: 1. How does knowledge of zakat affect public awareness in paying zakat on rice farming in Lembah Village? 2. How does religiosity affect public awareness in paying zakat on rice farming in Lembah Village? 3. How is the effect of knowledge of zakat and religiosity simultaneously on public awareness in paying zakat for rice farming in Lembah Village? The research used is quantitative. The population was 1,023 , and the sample consisted of 100 farmers in 
Lembah Village, Dolopo District, using non-probability sampling techniques through purposive sampling. The data collection technique used a questionnaire, while the data analysis used multiple linear analysis. Based on the results of data analysis conducted by researchers, it can be concluded that: Knowledge of zakat has a significant effect on public awareness with a tcount $>$ t-table, 3.278> 1.660 and multiple linear regression of 0.320 . Religiosity has no significant effect on public awareness with the value of tcount $>\mathrm{t}$ table, 1.757> 1.660 and multiple linear regression of 0.217. Knowledge of zakat and religiosity together significantly affects public awareness with the value of $f$ count, 11.688> 3.09 and $R$ Square's value of 0.441 .

Keywords: Zakat Knowledge, Religiosity, Community Awareness, Zakat For Rice Agriculture

\section{INTRODUCTION}

Indonesia has natural potential in the agricultural sector. Support of climate, soil fertility, and forests as water sources that cause the majority of the population to make their livelihoods as farmers. Agriculture plays an essential role in the overall economy of Indonesia. It is indicated by many residents or workers who depend on their livelihoods or work in the agricultural sector or from products derived from agriculture (Mubyarto, 1995). There is a dire condition because many Muslims in Indonesia experience various life problems, including poverty. What is even more worrying is that they are in the midst of a small part of society whose lives are high quality and even abundant in luxury. Because these wealthy people do not care about the fate of the poor, it has resulted in widespread social disparities (Baznas, 2019). When viewed from the background of the Indonesian population, many of the population or workforce who live or work in the agricultural sector or from agricultural products, it can be concluded that the potential for agricultural zakat in Indonesia is enormous. It means that the zakat fund for agriculture, which has enormous potential in Indonesia, must be utilized to contribute to the downturn of the ummah. (Ali, 2006).

Zakat is a spiritual obligation for a Muslim with a fundamental meaning, apart from being closely related to the divine aspect, it is 
also related to the aspect of justice. Al-Qur'an and hadith have mentioned the types of property that must be zakat, agricultural products, livestock products, trade, gold, silver, and money. However, this does not mean that other than these types of assets, zakat is not required. (Tebba, 2003). Zakat from agricultural products is a significant commodity in human life because agriculture is a material for humans to meet their food needs to stay alive. Concerning this agricultural zakat, al-Qur'an and al-Sunnah have explained the types of plants subject to compulsory zakat, rice, wheat, dates, and grapes. (Hidayat, 2015).

In the community, many problems arise and occur. The mismatch between theory and practice impacts the law both individually and in groups. Religiosity is identified with diversity. Religiosity is defined as how far the knowledge is, how strong the belief is, how much is the practice of worship and how deep is the appreciation of the religion one adheres. (J. P. Chalpin, 2002). Public awareness of agricultural zakat is closely related to knowledge and good community religiosity. This knowledge includes knowledge of zakat and the benefits of zakat on economic justice for Muslims. Knowledge makes individuals have a positive self-concept because, with the knowledge, they will be able to perceive themselves and create self-awareness in themselves to tithe. (Saad, 2003).

While high religiosity will lead to the ability to improve themselves in each individual so that someone who already can introspect themselves so that it creates self-awareness in someone, with high religiosity, the awareness within the individual will also increase. (Makmun, 2013). Lembah Village is one of the villages located in the Dolopo Subdistrict, Madiun Regency, where the average population works in the agricultural sector, especially rice crops. The agricultural potential in the area is quite significant because the agricultural area reaches 216 hectares. Each harvest from 1 hectare of an agricultural area can produce around 5-6 tons of rice. (Documentation of Lembah Village, 2020).

Seeing the extent of available land shows that the potential for zakat in the agricultural sector, especially rice in the region, is quite immense. However, the reality in people's lives, especially in Lembah Village, Dolopo Subdistrict, Madiun Regency, has long since been felt that there is still no full awareness of paying zakat for agricultural products. So far, the management of zakat in this sector has not been entirely appropriately managed, so that the zakat collected so far has 
not been submitted to an official institution established by the government. So far, zakat payments for agricultural products are only based on public awareness, and it is not uncommon for those who do not pay zakat for agricultural products. If seen at a glance, the people of Lembah Village from the breadth of rice fields and their social environment are very supportive of the creation of a religious community environment. It can be seen from the number of religious facilities and religious activities so that the collected agricultural zakat is quite large.

\section{LITERATURE REVIEW}

\section{Public Awareness}

Society is a collection of a group of people who live in an area (a particular place). According to Soerjono Soekanto, people are members of groups, both large and small, who live together in an area with certain limitations. Society is several people in the broadest sense and is bound by a culture they consider the same. (Soekanto, 1995). The word consciousness comes from the word "conscious," which means insaf, meaning that he feels he knows and understands. Based on this, the conscious attitude or behavior is always carried out in a state of knowing, understanding feeling, and being aware. Public awareness is fundamental to increase zakat in Indonesia, especially on agricultural zakat, because agricultural zakat has enormous potential to improve the economy of Indonesian people. The indicators of a person's consciousness are divided into two:

1. Awareness includes understanding and knowledge of the surrounding environment.

2. Consciousness also includes recognizing one's mental events. (Solso, 2007).

Soemarno Soedarsono explained that awareness is a manifestation of one's identity. It can be called a person who has an identity when the person concerned is reflected in his value system, perspective and behavior. (Soedarsono, 2000).

1. Value system; The value system has three components, consist of:

a. Reflection of conscience

Conscience reflection in psychology is identical to selfreflection or self-evaluation, analyzing and evaluating 
oneself through data and sources from within and from the surrounding environment to obtain a personal picture.

\section{b. Pride}

Self-esteem is defined as the dignity, degree, rank, prestige of an individual and is recognized by others (society) for one's status and position, manifested in self-respect and respect.

c. Fear of God Almighty

Being devoted to God Almighty is the spiritual way that humans take to gain consciousness. According to Muhammad Iqbal, piety to God means obeying the laws brought by the Prophet Muhammad SAW, meaning that the person is wise in acting, is strong, works hard and is integrated, and carries out Allah's orders away from His prohibitions in facing existing trials. (Iqbal, 1992).

2. The perspective

a. Togetherness

Efforts form awareness, an element of togetherness by building good relationships with oneself.

b. Intelligence

Efforts to form a quality personality, there is a selffoundation that humans must traverse to achieve the essence of personal resilience or a strong character, the Intelligence of life. Behavior

c. Genuine and polite hospitality

Sincere and courteous hospitality is respect and respect for others. With sincere and courteous hospitality, resilience and toughness, creativity and agility in action, coupled with the possession of an unyielding soul.

d. Resilient and tough

It is a form of awareness in the form of a self-attitude, resilient and resilient. Language is interpreted as an unyielding attitude in trying, agile, agile, and nimble. (Malikah, 2013).

\section{Knowledge of Zakat}


Etymologically, knowledge comes from the English word knowledge. In the Encyclopedia of Philosophy, it is explained that the definition of knowledge is a true belief (knowledge is justified, true belief). Meanwhile, according to Drs. Sidi Gazalba, knowledge is what is known or the work of knowing. The work to know in question results from knowing, being aware, aware, understanding, and clever. So it can be concluded that knowledge is the result of the process of human efforts to know. (Bahtiar, 2018).

Humans can develop knowledge because humans have a language capable of communicating information and the thoughts behind the information, and humans can develop their knowledge quickly and steadily.

Knowledge will significantly influence a person's behavior because starting from the knowledge that a person has will have more goals than behavior based on knowledge. The factors driving knowledge that subsequently serve as indicators of knowledge include: (Sintina, 2016).

\section{Know}

Defined as remembering previously learned material. What is included in this level of knowledge is to recall something specific from all the material studied.

2. Understand

Understanding is defined as the ability to describe a known object and interpret the material correctly.

\section{Awareness}

Awareness; a person is aware in the sense of knowing in advance of the object. Here, the meaning of awareness is that a person realizes that paying zakat is obligatory even he is afraid.

4. Applications / Practices

Application is defined when a person who already understands an object can use or apply the general principle to another situation.

After a person knows about zakat, he understands the importance of tithing and is aware of what encourages him to pay zakat and penalties for people who do not carry out zakat obligations.

Knowledge about himself, this knowledge includes things that have to do with the world and the hereafter, satisfaction in living life, respecting oneself, and understanding oneself. (Saad, 2003)

\section{Religiosity}


The word "religion" comes from the Latin "religion," whose root word is "Religare," which means "to bind." The point is that in religion (religion), in general, some rules and obligations must be carried out, all of which serve to bind a person or group of people concerning God among humans and the surrounding nature. According to the Big Indonesian Dictionary (KBBI), religiosity is devotion to religion, piety. Strong people may not be too strong but have very high awareness. According to Glock \& Stark, there are five indicators of religiosity, including: (Subandi, 2005).

1. The dimension of belief

The dimension of belief is the degree to which a person accepts dogmatic matters in his religion.

2. The Experience Dimension

The dimension of appreciation is the degree to which a person performs ritual obligations in his religion.

3. Dimensions of appreciation

The dimension of appreciation is the religious feelings or experiences that have been experienced and felt.

4. The dimension of knowledge

The dimension of knowledge is that a person knows about religious teachings, especially those in the holy book and others. This dimension can also be called the dimension of knowledge.

5. Behavioral dimensions

Behavioral dimensions measure the extent to which a person's behavior is motivated by religious teachings in social life.

High religiosity will lead to improving themselves in each individual so that someone who already can introspect himself creates self-awareness in a person. With high religiosity, the awareness within the individual will also increase.

\section{Zakat}

1. Definition of Agricultural Zakat

According to the language, the word zakat has several meanings, al-barakatu "blessing," al-nama "growth and development," ath-thaharatu "purity," and ash-shalahu "success." Agricultural zakat is one type of zakat maal whose object includes plants or plants of economic value such as grains, tubers, vegetables, fruits, ornamental plants, grasses. 


\section{Agricultural Zakat Nisab}

Nisab is the number of assets that must be paid zakat. If the property has reached the nisab, there is an obligation to pay the zakat. The Prophet SAW said that the plant zakat ratio is five wassaq. The size of 5 wassaq in Indonesia is equal to $750 \mathrm{~kg}$ of rice. So, if agricultural assets have reached at least the predetermined size, there is an obligation to pay zakat.

The calculation for 5 wassaq $=750 \mathrm{~kg}$ is as follows:

1 wassaq $=60$ sha ${ }^{\prime}$

5 wassaq $(5 \times 60$ sha ' $=300$ sha' $)$

1 sha' $=4$ mud

5 wassaq $(4$ x $300=1,200$ mud $)$

The size of zakat fitrah is $2.5 \mathrm{~kg}=1 \mathrm{sha}$ '

The size of 5 wassaq, if calculated according to the calculation of kilograms in Indonesia, is $5 \times 60 \times 2.5=750 \mathrm{~kg}$ of rice or $1,350 \mathrm{~kg}$ of rice.

3. Amount of Zakat on Agricultural Products

Plants and fruits are irrigated with rainwater or river water without incurring costs or energy from the owner and absorbing the water themselves. Then the zakat must be paid $1 / 10$ or $10 \%$ if they have reached the predetermined nisab. If supplied with a sprinkler or machine, which causes the farmer to spend money and energy, then the zakat is only $1 / 20$ of $5 \%$. (Huda, 2012).

\section{RESEARCH METHODS}

The research method used is survey research to obtain data from certain natural places by distributing questionnaires and conducting unstructured interviews to find out more in-depth matters from the respondents, the community rice farmers in Lembah Village, Dolopo District, Madiun Regency, East Java Province. The type of research used is quantitative research, in which the process of extracting information is manifested in the form of numbers as a tool to find information about how to know. Researchers use this type of research that is quantitative associative, which describes the relationship between two or more variables. 
The research variable is anything in the form determined by the researcher to be studied to obtain information about it, then conclude, which will be explained in the following chapters. This study uses several variables to be discussed, which include the dependent variable and the independent variable are:

a. Dependent Variable

The dependent variable in this study is public awareness in paying zakat.

b. Independent variable (Independent Variable)

The independent variables in this study are knowledge of zakat and religiosity.

\section{Operational definition}

An operational definition is a research variable intended to understand the meaning of each research variable before analysis, instruments, and measurement sources are carried out. The operational definition of each variable in the study is as follows:

a. Knowledge of zakat: Know (Know), understand, awareness, application, or practice.

b. Religiosity: The dimension of belief, the dimension of experience, the dimension of appreciation, the dimension of knowledge, the dimension of behavior.

c. Public awareness: Awareness includes understanding and knowledge of the surrounding environment. Awareness also includes recognizing a person about his mental events.

\section{Population}

The population is a generalization area consisting of objects or subjects with specific characteristics determined by the researcher to be studied and then conclude. The population referred to in this study was 1,023 rice farmers in Lembah Village, Dolopo District. The criteria are as follows: Islam, sensible, reaches the nisab.

\section{Samples}

The sample is a part of a particular population that is of concern. This study uses the Solvin formula as a basis for determining the appropriate number of samples, while the results of the calculation using this formula are as follows:

$$
\mathrm{n}=\frac{N}{1+N e^{2}}=\frac{1.023}{1+1.023(0,1)^{2}}=91.095=92 \text { rounded to } 100
$$




\section{Sampling technique}

The sampling technique is a method or way of determining the sample and the size of a sample. The sampling technique used in this study is non-probability sampling through purposive sampling, which is a sampling technique with specific considerations. This technique is used in order to obtain a representative sample under the criteria set by the researcher.

\section{RESULTS AND DISCUSSION}

A. Instrument Testing Results

1. Test the validity

The validity test is used to measure whether a questionnaire is valid or not.

Table 1

Zakat Knowledge Validity Test Results (X1)

\begin{tabular}{|l|l|l|l|l|}
\hline Variable & $\begin{array}{l}\text { Item } \\
\text { Penyataan }\end{array}$ & $\begin{array}{l}\mathrm{R} \\
\text { Hitung }\end{array}$ & $\mathrm{R}$ Tabel & Keterangan \\
\hline \multirow{3}{*}{$\begin{array}{l}\text { Zakat } \\
\text { knowledge }\end{array}$} & $\mathrm{X} 1.1$ & 0,607 & 0,361 & Valid \\
\cline { 2 - 5 } & $\mathrm{X} 1.2$ & 0,714 & 0,361 & Valid \\
\cline { 2 - 5 } & $\mathrm{X} 1.3$ & 0,427 & 0,361 & Valid \\
\cline { 2 - 5 } & $\mathrm{X} 1.4$ & 0,460 & 0,361 & Valid \\
\cline { 2 - 5 } & $\mathrm{X} 1.5$ & 0,506 & 0,361 & Valid \\
\cline { 2 - 5 } & $\mathrm{X} 1.6$ & 0,674 & 0,361 & Valid \\
\cline { 2 - 5 } & $\mathrm{X} 1.7$ & 0,413 & 0,361 & Valid \\
\cline { 2 - 5 } & $\mathrm{X} 1.8$ & 0,606 & 0,361 & Valid \\
\cline { 2 - 5 } & $\mathrm{X} 1.9$ & 0,632 & 0,361 & Valid \\
\cline { 2 - 5 } & $\mathrm{X} 1.10$ & 0,375 & 0,361 & Valid \\
\hline
\end{tabular}

Based on table 1 above, it can be concluded that the overall statement on the knowledge variable of zakat is declared valid because all statement items have a value of $r$ count greater than $r$ table, 0.361 .

Table 2

Religiosity Validity Test Results (X2) 


\begin{tabular}{|l|l|l|l|l|}
\hline Variable & $\begin{array}{l}\text { Item } \\
\text { Penyataan }\end{array}$ & $\begin{array}{l}\text { R } \\
\text { Hitung }\end{array}$ & R Tabel & Keterangan \\
\hline Religiusitas & X2.1 & 0,462 & 0,361 & Valid \\
\cline { 2 - 5 } & X2.2 & 0,462 & 0,361 & Valid \\
\cline { 2 - 5 } & X2.3 & 0,489 & 0,361 & Valid \\
\cline { 2 - 5 } & X2.4 & 0,557 & 0,361 & Valid \\
\cline { 2 - 5 } & X2.5 & 0,472 & 0,361 & Valid \\
\cline { 2 - 5 } & X2.6 & 0,416 & 0,361 & Valid \\
\cline { 2 - 5 } & X2.7 & 0,558 & 0,361 & Valid \\
\cline { 2 - 5 } & X2.8 & 0,423 & 0,361 & Valid \\
\cline { 2 - 5 } & X2.9 & 0,800 & 0,361 & Valid \\
\cline { 2 - 5 } & X2.10 & 0,767 & 0,361 & Valid \\
\hline
\end{tabular}

Source: Processed products of SPSS v.21 2020

Based on table 2 above, it can be concluded that the overall statement on the religiosity variable is declared valid because all statement items have a value of $r$ count greater than $r$ table 0.361 .

Table 3

Results of Public Awareness Validity Test (Y)

\begin{tabular}{|l|l|l|l|l|}
\hline Variable & $\begin{array}{l}\text { Item } \\
\text { Penyataan }\end{array}$ & $\begin{array}{l}\mathrm{R} \\
\text { Hitung }\end{array}$ & R Tabel & Keterangan \\
\hline \multirow{3}{*}{$\begin{array}{l}\text { Community } \\
\text { awareness }\end{array}$} & Y.1 & 0,677 & 0,361 & Valid \\
\cline { 2 - 5 } & Y.2 & 0,629 & 0,361 & Valid \\
\cline { 2 - 5 } & Y.3 & 0,444 & 0,361 & Valid \\
\cline { 2 - 5 } & Y.4 & 0,545 & 0,361 & Valid \\
\cline { 2 - 5 } & Y.5 & 0,418 & 0,361 & Valid \\
\cline { 2 - 5 } & Y.6 & 0,495 & 0,361 & Valid \\
\cline { 2 - 5 } & Y.7 & 0,547 & 0,361 & Valid \\
\cline { 2 - 5 } & Y.8 & 0,528 & 0,361 & Valid \\
\cline { 2 - 5 } & Y.9 & 0,493 & 0,361 & Valid \\
\cline { 2 - 5 } & Y.10 & 0,365 & 0,361 & Valid \\
\hline
\end{tabular}

Source: Processed products of SPSS v.21 2020

Based on table 3 above, it can be concluded that the overall statement on the public awareness variable is declared valid because all statement items have a value of $r$ count greater than $r$ table, 0.361 . 
Table 4

Reliability Test Results

\begin{tabular}{|l|l|l|}
\hline Variable & $\begin{array}{l}\text { Cronbach's } \\
\text { Alpha }\end{array}$ & Keterangan \\
\hline Zakat knowledge (X1) & 0,735 & Reliabel \\
\hline Religiusitas (X2) & 0,728 & Reliabel \\
\hline $\begin{array}{l}\text { Community awareness } \\
\text { (Y) }\end{array}$ & 0,690 & Reliabel \\
\hline
\end{tabular}

From table 4 above, it can be concluded that each variable has a Cronbach's alpha of more than 0.60 so that the data can be said to be reliable, which means that the questionnaire used in this study is a reliable one; the data can be used for measurement and subsequent research.

b. Multiple linear regression analysis

Multiple linear regression analysis analyzes the relationship and influence between one dependent variable on two or more independent variables.

Table 5

Results of Multiple Linear Regression Analysis

\begin{tabular}{|c|l|l|l|l|l|}
\hline & \multicolumn{2}{|l|}{$\begin{array}{l}\text { Unstandardize } \\
\text { d Coefficients }\end{array}$} & $\begin{array}{l}\text { Standardized } \\
\text { Coefficients }\end{array}$ & & \\
\cline { 2 - 5 } Model & $\mathrm{B}$ & $\begin{array}{l}\text { Std. } \\
\text { Error }\end{array}$ & Beta & $\mathrm{t}$ & Sig. \\
\hline $1 \quad$ (Constant) & 16,682 & 5,250 & & 3,177 &, 002 \\
$\quad \begin{array}{l}\text { Zakat } \\
\text { knowledge } \\
\text { Religiusitas }\end{array}$ &, 320 &, 098 &, 332 & 3,278 &, 001 \\
&, 217 &, 124 &, 178 & 1,757 &, 082 \\
\hline
\end{tabular}

a. Dependent Variable: Community awareness

Source: Processed products of SPSS v.21 2020 
Based on table 5 above, the multiple linear regression equation can be arranged as follows:

$\mathrm{Y}=16.682+0.320(\mathrm{X} 1)+0.217(\mathrm{X} 2)$

The equation above can be explained as follows:

1) The constant value has a positive value of 16.682. It shows that if the variables of zakat knowledge and religiosity are considered constant or constant (0), then the level of public awareness is 16.682 .

2) The coefficient value of the knowledge variable of zakat is 0.320 . The coefficient value is positive so that there is a unidirectional relationship between zakat knowledge and public awareness. The higher the knowledge of zakat, the higher the public awareness.

3) The coefficient value of the religiosity variable is 0.217 . The coefficient value is positive so that there is a unidirectional relationship between religiosity and public awareness. The higher the religiosity, the higher the public awareness.

c. T-test

Table 6

T-test results

\begin{tabular}{|c|c|c|c|c|c|}
\hline \multirow[b]{2}{*}{ Model } & \multicolumn{2}{|c|}{$\begin{array}{l}\text { Unstandardize } \\
\text { d Coefficients }\end{array}$} & \multirow{2}{*}{$\begin{array}{l}\text { Standardize } \\
\mathrm{d} \\
\text { Coefficients } \\
\text { Beta }\end{array}$} & \multirow[b]{2}{*}{$\mathrm{t}$} & \multirow[b]{2}{*}{ Sig. } \\
\hline & B & $\begin{array}{l}\text { Std. } \\
\text { Error }\end{array}$ & & & \\
\hline 1 (Constant) & 16,682 & 5,250 & & 3,177 & ,002 \\
\hline $\begin{array}{l}\text { Zakat } \\
\text { knowledge }\end{array}$ & ,320 & ,098 & ,332 & 3,278 & ,001 \\
\hline Religiosity & ,217 &, 124 & , 178 & 1,757 & ,082 \\
\hline
\end{tabular}

a. Dependent Variable: Community awareness

Source: Processed products of SPSS v.21 2020

1) The Influence of Knowledge of Zakat on Public Awareness

The $\mathrm{t}$-count value is $3.278>\mathrm{t}$ table is 1.660 , so there is an influence between the knowledge of zakat on public awareness or 
the sig value of $0.001<0.05$, it is significant. So, knowledge of zakat has a significant effect on public awareness.

2) The Effect of Religiosity on Public Awareness

The t-count value is $1.757>\mathrm{t}$ table is 1.660 , so there is an influence between religiosity on public awareness or the sig value $0.082>0.05$. It is not significant. So, religiosity has no significant effect on public awareness.

d. F test (Simultaneous Test)

Table 7

Test Results $\mathrm{f}$

ANOVA

\begin{tabular}{|ll|l|l|l|l|l|}
\hline Model & $\begin{array}{l}\text { Sum of } \\
\text { Squares }\end{array}$ & Df & $\begin{array}{l}\text { Mean } \\
\text { Square }\end{array}$ & F & Sig. \\
\hline 1 & Regression & 129,998 & 2 & 64,999 & 11,688 & $.000^{\mathrm{b}}$ \\
& Residual & 539,442 & 97 & 5,561 & & \\
\multicolumn{1}{|c|}{ Total } & 669,440 & 99 & & & \\
\hline
\end{tabular}

a. Dependent Variable: Community awareness

b. Predictors: (Constant), Religiusitas, Zakat knowledge

Source: Processed products of SPSS v.21 2020

Based on table 7, it is obtained that the value of the table is from df $1=$ $2 \mathrm{df} 2=100-2-1=97$ and produces a table $(2 ; 97)$ of 3.09. Because fhittung > ftabel is 11.688> 3.09. So it can be concluded that $\mathrm{HO}$ is rejected and $\mathrm{H} 1$ is accepted, which means that knowledge of zakat and religiosity affects public awareness.

e. The coefficient of determination (R2)

Table 8 


\begin{tabular}{|l|l|l|l|l|}
\hline Model & $\mathrm{R}$ & $\mathrm{R}$ & $\begin{array}{l}\text { Std. An error } \\
\text { Squared } \\
\text { Square }\end{array}$ & $\begin{array}{l}\text { Estimate } \\
\text { Square }\end{array}$ \\
\hline 1 & $.441^{\mathrm{a}}$ &, 194 &, 428 & 2,35823 \\
\hline
\end{tabular}

a. Predictors: (Constant), Religiusitas, Zakat knowledge

b. Dependent Variable: Community awareness

Source: Processed by SPSS v.21 2020

Based on table 8 above, the coefficient of determination in the table model summary obtained the R Square value of 0.441 or $44.1 \%$. So that the presentation of the contribution of the influence of zakat knowledge and religiosity on public awareness is $44.1 \%$, while the remaining $55.9 \%$ is influenced by other factors not included in this study.

\section{DISCUSSION}

1. The Effect of Knowledge of Zakat on Public Awareness

The regression test results for the knowledge variable of zakat have a positive coefficient of 0.320 , so that there is a unidirectional relationship. The higher the knowledge of zakat, the higher the awareness of the community in paying zakat on rice farming in Lembah village, Dolopo sub-district. Meanwhile, based on the t-test, with a t-count of 3.278> t table of 1.660, there is an effect of knowledge of zakat on public awareness, or the sig value of 0.001 $<0.05$ is significant. So, knowledge of zakat has a significant effect on public awareness in paying zakat for rice farming.

2. The Influence of Religiosity on Public Awareness

The test results for the religiosity variable have a positive coefficient of 0.217 . There is a unidirectional relationship, where the higher the religiosity, the higher the public awareness in paying zakat on rice farming in the village of Lembah Dolopo. Meanwhile, based on the ttest, it has a t-count of 1.757> 1.660, so there is an effect of religiosity on public awareness, or the sig value of $0.082>0.05$ is not significant. 
So, religiosity has no significant effect on public awareness in paying zakat on rice farming.

3. The Influence of Knowledge of Zakat and Religiosity on Public Awareness

Based on the results of the simultaneous testing, it shows that the variables (X1 and X2) have a significant effect on variable $\mathrm{Y}$. Knowledge of zakat and religiosity has a significant effect on public awareness as seen from the value of fcount $>$ f-table, which is 11.688> 3.09 and a significance value of $0.000<0.05$. In comparison, the coefficient of determination (R2) obtained the R Square value of 0.441 . It shows that the magnitude of the influence of knowledge and religiosity on public awareness is $44.1 \%$.

\section{CONCLUSION}

1. Knowledge of zakat (X1) affects public awareness (Y) in paying zakat for rice farming in Lembah village, Dolopo sub-district, Madiun Regency.

2. Religiosity (X2) affects public awareness (Y) in paying zakat on rice farming in Lembah village, Dolopo sub-district, Madiun Regency.

3. Knowledge of zakat and religiosity together significantly affects public awareness in paying zakat for rice farming in Lembah village, Dolopo sub-district, Madiun Regency.

\section{REFERENCE}

Amsal Bakhtiar, Filsafat Ilmu, (Jakarta : PT Raja Grafindo Persada, 2018), 85.

Antonius Atosokhi Gea, dkk, Relasi Dengan Diri Sendiri, (Jakarta :

Elek Media Komputindo, 2002), 7.

Departemen Pendidikan dan Kebudayaan Indonesia, Kamus Besar

Bahasa Indonesia (KBBI), (Jakarta : Balai Pustaka, 2005), 944.

Departemen Pendidikan Nasional, Kamus Besar Bahasa Indonesia (Jakarta : Balai Pustaka, 2005), 975.

Didin Hafidhuddin, Zakat dalam Perekonomian Modern, (Jakarta: Gema Insani Press, 2002), 7.

Kabupaten Madiun, 2020 
Fatah Hidayat, Zakat Hasil Pertanian Kontemporer, Jurnal Fikih, No 2 Volume 13, 2015, 51.

http://pusat.baznas.go.id/wpcontent/2016.pdf Di akses pada tanggal 20 November 2019, Pukul 10.23.

J. P. Chalpin, Kamus Lengkap Psikologi, (Jakarta : PT Raja Grafindo Persada, 2002), 450.

Magfira dan Thamrin Logawali, Community awareness Dalam

Melakukan Pembayaran Zakat Pertanian Padi Di Desa

Bontomacinna Kec. Gantarang Kabupaten Bulukumba, Jurnal

Fakultas Ekonomi dan Bisnis Islam UIN Alauddin Makassar, Volume 5, Nomor 1, 2017.

Magfira dan Thamrin Logawali, Community awareness Dalam Melakukan Pembayaran Zakat Pertanian Padi Di Desa Bontomacinna Kec. Gantarang Kabupaten Bulukumba, Jurnal Fakultas Ekonomi dan Bisnis Islam UIN Alauddin Makassar, Volume 5, Nomor 1, 2017.

Makmun, Life Skill Personal Self Awereness : Kecakapan Mengenal Diri, (Sleman : Deepublish, 2017), 209.

Malikah, Kesadaran Diri Proses Pembentukan Karakter Islam, Jurnal Al-Ulum Institut Agama Islam Negeri Sultan Amai Gorontalo, Volume 12 Nomor 1, 2013.

Masrur Huda, Syubhat Seputar Zakat, (Solo : Anggota IKAPI Perpustakaan Nasional, 2012), 63.

Mubyarto, Pengantar Ekonomi Pertanian, cet. Ket 4 (Jakarta : Pustaka LP3ES Indonesia, 1995), 12.

Muhammad Iqbal, Reconstruction in Islam, (Jakarta : Tintamas, 1982), 45.

Nanang Martono, Metode Penelitian Kuantitatif, edisi II (cet. VII : Jakarta : Kencana Prenada Media Group, 2014), 17.

Nuruddin Ali, Zakat Sebagai Instrumen Dalam Kebijakan Fiskal, Edisi I (Jakarta : PT Raja Grafindo Persada, 2006), 1.

Robert L. Solso, dkk, Psikologi Kognitif, (Erlangga, 2007), 240.

Saad, Perkelahian Pelajar : Potret Siswa SMU di DKI Jakarta, (Yogyakarta : Galang Press, 2003), 25.

Soerjono Soekanto, Sosiologi Suatu Pengantar, (Jakarta : PT Raja Grafindo Persada, 1995), 162.

Subandi, Psikologi Agama\& Kesehatan Mental (Yogyakarta: Pustaka Pelajar, 2013),87

Sudirman Tebba, Sosiologi Hukum Islam (Yogyakarta : UII Press, 2003), 48. 
Sugiono, Metode Penelitian Kuantitatif, Kualitatif dan R \& D (Bandung: Alfabeta, 2019), 137.

Syofian Siregar, Metode Penelitian Kuantitatif, (Jakarta : Kencana, 2017), 16.

Teza Sintina, Neneng, Nurdin, Pengaruh Pengetahuan dan Kepercayaan Terhadap Minat Masyarakat Membayar Zakat di Sinergi Foundation Kota Bandung, (Prosinding Keuangan dan Perbankan Syariah, 2016), 301.

Tony Wijaya, Analisis Data Penelitian Menggunakan SPSS, (Yogyakarta : Universitas Atma Jaya Yogyakarta), 55.

Wiratna Sujarweni, Metodologi Penelitian Bisnis Dan Ekonomi, (Yogyakarta: PT Pustaka Baru, 2015), 43. 